\title{
Suspended Dead Wood Decomposes Slowly in the Tropics, with Microbial Decay Greater than Termite Decay
}

\author{
Stephanie Law, ${ }^{1 *}$ Paul Eggleton, ${ }^{3}$ Hannah Griffiths, ${ }^{1}$ Louise Ashton,,${ }^{2,3}$ and \\ Catherine Parr ${ }^{1,4,5}$
}

\begin{abstract}
${ }^{1}$ Department of Earth, Ocean and Ecological Sciences, School of Environmental Sciences, University of Liverpool, Liverpool, UK; ${ }^{2}$ School of Biological Sciences, The University of Hong Kong, Hong Kong, China; ${ }^{3}$ Life Sciences Department, Natural History Museum, London, UK; ${ }^{4}$ Department of Zoology and Entomology, University of Pretoria, Pretoria 0002, South Africa; ${ }^{5}$ School of Animal, Plant and Environmental Sciences, University of the Witwatersrand, Wits, Johannesburg 2050, South Africa
\end{abstract}

\begin{abstract}
Coarse woody debris (CWD) is an important pool of carbon in forest ecosystems and is present in all strata as fallen, standing or suspended CWD. However, there are relatively few decomposition studies of CWD in tropical forests compared with temperate forests, and research on suspended CWD in particular has largely not been attempted. Termites are important decomposers in tropical ecosystems yet their role relative to microbial decomposers and the importance of the vertical location of CWD has rarely been considered. For the first time, we examined the relative contribution of macro-invertebrates (predominantly termites) and microbes to the decay of suspended and ground-placed (fallen) CWD in lowland, tropical rainforest. We set up wood baits (Pinus radiata) with and without termite access, and measured wood mass loss after 1 year. Mass loss of groundplaced CWD assays was over four times greater
\end{abstract}

than suspended CWD assays. Termite decomposition was vertically stratified with termites having a large relative contribution to the decomposition of ground-placed CWD and a negligible contribution to the decomposition of suspended CWD. In contrast, the effect of microbes on decomposition was low and not vertically stratified. Although our results support the findings of temperate studies in that decomposition of CWD is dependent on its physical location, we show that in tropical rainforests this is predominantly due to greater termite decomposition on the forest floor. Suspended CWD remains an important carbon sink due to slow microbial decay until it falls to the forest floor where it is more accessible to termites.

Key words: carbon pool; coarse woody debris; decomposition; fallen dead wood; microbe; suspended dead wood; termite; tropical rainforest.
Received 18 June 2018; accepted 25 November 2018; published online 2 January 2019

Author Contributions SL designed the study, performed research, analyzed data and wrote the paper. HG and LA designed the study and contributed to field work. PE and CP designed the study and wrote the paper.

*Corresponding author; e-mail: stephanie.law@liverpool.ac.uk

\section{HighLIGHTS}

- In rainforests, termite decay of dead wood depends on its vertical location.

- As a result, suspended dead wood decomposes more slowly than fallen dead wood.

- Most biotic decay of suspended dead wood in rainforest is attributable to microbes. 


\section{Aim ANd InTROduction}

Dead wood is an important component in forest ecosystems. In addition to the storage and cycling of organic matter (carbon) and nutrients (for example, nitrogen), dead wood provides critical microhabitats, helps seedling establishment, increases the structural diversity of the forest, alters microenvironments and promotes biological diversity (Harmon and others 1986; Parks and Shaw 1996). Dead wood is a significant component of the carbon pool in forests, storing about $8 \%$ of the global carbon stock in forests at $73 \pm 6 \mathrm{Pg} \mathrm{C}$ (Pan and others 2011). This figure rises in tropical forests where dead wood has been estimated to account for between 17 and $33 \%$ of total aboveground carbon storage, reaching 44 to $48 \mathrm{Mg} \mathrm{C} \mathrm{ha-1}$ across a range of tropical forest sites (Delaney and others 1998; Clark and others 2002; Rice and others 2004; Iwashita and others 2013).

Woody debris exists as a wide variety of forms and is frequently classified based on size and vertical location. Although definitions between studies differ marginally, woody debris is broadly divided into fine and coarse woody debris (FWD and CWD) based on the minimum diameter of dead wood (see Harmon and others 1986; Palace and others 2012). CWD is further divided into types depending on its position in the forest: It can be standing as dead trees (snags), fallen (lying on the forest floor, also referred to as 'downed') (Harmon and others 1986; Delaney and others 1998) or suspended in the canopy or understory (still attached to or caught in either living or dead woody plants) (Harmon and Sexton 1996).

In some tropical dry forest sites, the biomass of standing and suspended CWD together can exceed that of dead wood on the forest floor (Maass and others 2002; Calderón-Cortés and others 2018). Furthermore, in disturbed tropical ecosystems standing and suspended CWD can account for as much as $98 \%$ of the total CWD (Palace and others 2012). However, this figure is generally lower in undisturbed moist or wet tropical forests where standing CWD accounts for between 9 and $44 \%$ of total CWD (Palace and others 2012), yet remains an important carbon pool storing between 3.1 and 18.5 Mg C ha ${ }^{-1}$ (Clark and others 2002; Rice and others 2004; Iwashita and others 2013). Although no studies, to our knowledge, distinguish between the contribution made by standing and suspended dead wood to the carbon pool in tropical forests, a 1.7 -fold increase in fallen dead wood in a tropical dry forest following strong winds and hurricanes (Harmon and others 1995) indicates that a sub- stantial amount of dead wood can remain suspended above the forest floor until it is dislodged by a disturbance. The processes responsible for the decay of suspended CWD are important as they influence the rate at which CWD is released to the forest floor and so determine carbon and nutrient inputs to the ecosystem (Fonte and Schowalter 2004). Furthermore, suspended dead wood contributes to nutrient inputs to the soil prior to falling to the forest floor as it significantly increases nutrient flux via throughfall (Maass and others 2002).

A lack of data on the distribution and decay rates of dead wood has resulted in the inclusion of dead wood in global carbon models in only a generalized form (Cramer and others 2001; Weedon and others 2009). Variation in decay rates of dead wood is a major source of uncertainty in estimating the terrestrial carbon pool and predicting future emissions of $\mathrm{CO}_{2}$ (Harmon and others 1986; Weedon and others 2009). This is compounded by the lack of empirical studies on decay rates in subtropical and tropical forests, which harbor more than half of the world's carbon stock (Weedon and others 2009; Pan and others 2011; Seibold and others 2015).

Decomposition by microbes and wood boring/consuming insects can determine the longevity and turnover of carbon stored in dead wood (Chambers and others 2001; Mackensen and others 2003; Cornwell and others 2009). Decay rates of dead wood depend on both biotic (for example, species of wood and of decomposer species, plant traits) and abiotic factors (for example, humidity, temperature) at all scales, from regional to local (microclimatic). It is well established that fungi, beetles and termites are key decomposer groups, using dead wood as a food resource and mobilizing nutrients (Harmon and others 1986; Cornwell and others 2009; Ulyshen 2016).

Traditionally, microbial activity, predominantly fungal, has been thought to drive dead wood decomposition on fallen CWD on the forest floor, particularly in temperate systems (Harmon and others 1986; Cornwell and others 2009; Ulyshen 2016). However, wood-feeding insects also contribute to the decomposition of dead wood directly by enzymatic digestion and indirectly by substrate alteration, promoting fragmentation of the substrate and facilitating further colonization by microbes (Ulyshen 2016). Yet, surprisingly few studies have quantified the contribution of decomposer insects to the decay of dead wood (Ulyshen and Wagner 2013); most of these studies were in temperate regions. 
In the tropics, wood-feeding termites are likely to have a large role in the decay of dead wood and the cycling of nutrients (Wood and Sands 1978; Torres and González 2005; Cornwell and others 2009; Ulyshen and others 2016). Termites can excavate their nests within dead wood, decomposing dead wood in situ, but also transport dead wood to their nest before it is decomposed (Wood 1978; Wood and Sands 1978). Throughout Africa and Asia, the 'fungus-growing' termites, Macrotermitinae, contribute significantly to wood decomposition (Ulyshen 2016). Although the contribution of termites to the decay of dead wood in the tropics is thought to be substantial, it is also highly variable and patchy in occurrence as termite attack is stochastic (Songwe and others 1995; Takamura and others 2001; Cheesman and others 2017). Furthermore, termite decay can be specific to wood species as attack rates can also be dependent on plant traits, such as wood density, chemical composition and bark coverage (Takamura and others 2001; Liu and others 2015).

Temperature and moisture gradients have been shown to influence decomposition rates, principally through effects on decomposer communities (Harmon and others 1986). At a continental scale, increased temperatures and humidity are linked to greater rates of decay (Meentemeyer and others 1978, 1984; Moore and others 1999; Chambers and others 2000; Mackensen and others 2003). However, studies demonstrating these patterns in climate and decomposition are largely restricted to comparisons between temperate and boreal forests where microbes are the dominant driver in decomposition. In tropical forests, moisture is less useful at predicting decay rates of wood as high moisture content has been shown to both increase decay rates (Cheesman and others 2017) or conversely slow them under very saturated conditions (Torres and Gonzalez 2005; Song and others 2017). At a local scale, factors such as plant traits and the colonization of dead wood by wood-feeding insects explain more of the variation in decay rates than differences in climate (Bradford and others 2014).

In forests, the abiotic and biotic factors that influence decomposition vary spatially, including at different heights on a tree (Unterseher and Tal 2006; Roisin and others 2006; Madigosky 2004); thus, decomposition of dead wood is likely to be dependent on its both size and vertical position in the forest. Empirical studies have shown that decay rates of FWD are generally higher than those of CWD (Harmon and others 1995), and decay rates of fallen CWD are higher than those of standing CWD in both tropical forests (Song and others
2017) and temperate forests (Dunn and Bailey 2012; Onega and Eickmeier 1991). Yet, suspended dead wood is rarely accounted for in studies on decay rates and this remains a significant knowledge gap. This study and the study by Gora and others (In press a, b) represent the first to look in detail at the decomposition or residence time of suspended CWD in tropical rainforest. The few studies that have considered decomposition of suspended CWD took place in temperate forests and found slower rates of decay compared with fallen CWD (Swift and others 1976; Rice and others 1997).

Our study therefore addresses this research gap by quantifying the rates of decomposition of suspended dead wood in tropical forest. In addition, we quantify the contribution of microbes and macro-invertebrates, particularly termites, to the decomposition of both fallen and suspended dead wood. Specifically, we address the following research questions:

1. Do decomposition rates of CWD vary between fallen CWD and suspended CWD in a tropical rainforest system? To test this, we compared decomposition rates of experimental wood blocks at ground level with wood blocks placed in the understory and canopy of trees. We hypothesized that decomposition rates of suspended CWD would be slower than groundplaced CWD due to drier conditions, which slow rates of fungal colonization and reduce termite foraging and attack.

2. How is the relative contribution of microbes and macro-invertebrates to decomposition partitioned and does this differ with height? To test this, we compared the decomposition of experimental wood blocks that either allowed entry of or excluded macro-invertebrates. We expected the relative contribution of macro-invertebrates (termites) to be greater than microbes for ground-placed CWD and that this contribution would decrease with height for suspended CWD. Due to high termite densities on the ground and lower termite densities in trees, along with the disconnection between suspended wood blocks and the ground, we expected the likelihood of discovery by macroinvertebrates (termites) to decrease with increasing height from the ground.

3. Are abiotic conditions that are thought to influence decomposition rates, specifically temperature and humidity, vertically stratified? With increasing height from the ground, as a result of less shading by canopy vegetation, we 
expected to find higher mean and maximum values of temperature but lower mean and minimum values of humidity.

\section{MethodS}

\section{Field Site}

The study was in lowland, old-growth dipterocarp rainforest in Maliau Basin Conservation Area, Sabah, Malaysia. $\left(4^{\circ} 44^{\prime} 35^{\prime \prime}\right.$ to $55^{\prime \prime} \mathrm{N}$ and $116^{\circ} 58^{\prime} 10^{\prime \prime}$ to $30^{\prime \prime} \mathrm{E}$; mean annual rainfall $2838 \mathrm{~mm} \pm 93$ $\mathrm{mm})$. All sampling took place within four control plots which form part of a larger experiment established as part of the BALI project (Biodiversity And Land-use Impacts on tropical ecosystem function) (see Griffiths and others 2017), each measuring $50 \mathrm{~m} \times 50 \mathrm{~m}$ and spaced at least $100 \mathrm{~m}$ apart. Within each plot, three trees were selected that allowed the attachment of experimental wood blocks in the canopy. Although tree selection based on species was not possible due to the limited number of tall trees safe to climb within each $50 \mathrm{~m} \times 50 \mathrm{~m}$ plot, there was considerable overlap in species among plots: Of the 24 trees, 22 were Dipterocarpaceae belonging to the genera Parashorea or Shorea, and only two trees were nondipterocarps (Scaphium macropodum Beumee and Santiria laevigata Blume). All trees were either emergent or reached the high canopy within the plot, and each tree was measured using a tape measure: $54 \%$ were between 30 and $39 \mathrm{~m}$ tall, $33 \%$ were $40 \mathrm{~m}$ or taller, and $13 \%$ were below $30 \mathrm{~m}$. The shortest tree was $27 \mathrm{~m}$ tall.

\section{Monitoring Wood Decomposition}

We used a standard protocol for examining the relative influence of microbes and macro-invertebrates (termites) on wood decay as developed by Cheesman and others (2017). Following their recommendations, we used a standard assay of Pinus radiata D.Don wood blocks, known to be susceptible to termite attack (Standards Australia A56042005) and used as part of a wider global wood block study (Cheesman and others 2017). Untreated, planed planks of $P$. radiata were cut into blocks $9 \mathrm{~cm} \times 9 \mathrm{~cm} \times 5 \mathrm{~cm}$, within the specified range of minimum diameters $(2.5 \mathrm{~cm}$ to $15 \mathrm{~cm})$ for CWD (see Harmon 1986; Palace and others 2012). Any wooden blocks with knots or deformations, which may preferentially encourage termite attack, were discarded. All wooden blocks were first dried at $60^{\circ} \mathrm{C}$ or higher for $48 \mathrm{~h}$ to a constant mass. Each block was sealed in a fine nylon mesh bag $(300-\mu \mathrm{m}$ mesh-diameter nylon PlastOk ${ }^{\mathrm{TM}}$, Merseyside, UK) that was either "open" or "closed." Open blocks were enclosed within mesh bags with holes cut into the mesh to allow macro-invertebrates to enter; closed blocks had no holes in the mesh bags and showed the influence of microbial decay only. The edges of the mesh were folded several times and sealed with large stainless-steel staples to prevent macro-invertebrates from entering at the sealed ends. Most tropical-invertebrate-mediated wood decay is due to termites (Wood and Sands 1978; Bignell and Eggleton 2000; Torres and Gonzalez 2005; Cheesman and others 2017; Griffiths and others, in review); as such, we will refer to termite decay rather than to macro-invertebrate decay when considering the effect of open mesh bags on the decomposition of wood blocks.

To measure fallen CWD decomposition across each plot, ten blocks (five open blocks and five closed blocks) were placed on the ground $(n=40)$. All blocks were separated by $10 \mathrm{~m}$. Blocks were placed on the ground in July 2016 and collected 12 months later. To measure suspended CWD decomposition, on three emergent trees within each plot, blocks were placed in (open/closed) pairs at $10-\mathrm{m}$ vertical intervals from the ground to as high as possible within the canopy (height range from 10 to $40 \mathrm{~m}$ ). The location of each block was recorded as either the understory if blocks were placed on the trunk below any arterial branches or the canopy if blocks were placed on the trunk above any arterial branches. In total, 48 blocks were placed in the understory and 48 blocks in the canopy. Ordinarily, suspended dead wood is prevented from falling to the ground because of direct connections with either living or dead trees. Therefore, to simulate this, blocks were nailed to the trunk so that blocks were in direct contact with the tree trunk to enable discovery by decomposers. All blocks placed above the ground were set between February and May 2016 and were removed after 350-354 days.

On collection, wood blocks were removed from the mesh bag, any exterior (non-termite-produced) adhering soil was brushed off, and the blocks dried at $60^{\circ} \mathrm{C}$ for 5 days (or until there was no further loss in mass). Blocks with obvious termite attack were broken open, and any soil translocated by termites was removed and separated from the wood. Dry mass of the remaining wood was recorded.

We collected data on abiotic conditions by placing ibuttons ${ }^{\circledR}$ (Thermocron, model DS1923) at 5-m vertical intervals from the ground to the canopy on the largest sampled tree within each plot. At each 
height, ibuttons ${ }^{\circledR}$ were hung within a plastic cup to protect them from rain, and air vents were cut into the side of each cup and left to run continuously for 5 days. Temperature and humidity were recorded by the ibuttons ${ }^{\circledR}$ on the hour and every $30 \mathrm{~min}$, respectively.

\section{Data Analysis}

All analyses were carried out using $\mathrm{R}$ version 3.4.4 (R Core Team 2018). To account for differences in the initial weight of blocks, we calculated proportional mass loss for each block using the following equation:

proportional mass loss $=\left(\frac{\text { initial mass }- \text { final mass }}{\text { initial mass }}\right)$

To test for differences among proportional mass loss, we first logit transformed the data, as recommended for proportional data (Warton and Hui 2011), and used linear mixed models in the 'Ime4' package (Bates and others 2015) to assess whether mesh type (open/closed), stratum (canopy/understory/ground) or the interaction between these factors influenced proportional mass loss (for example, model $\leftarrow$ lmer(proportional mass loss mesh type * strata $+($ (lplot $))$. We included a random factor of plot to account for pseudo-replication within each plot. A top-down approach was used to arrive at the best descriptive model (Zuur and others 2009). All fixed effects and interactions were sequentially removed until a reduced minimum model was obtained. Chi-squared likelihood ratio tests were used to assess the loss of explanatory power following the removal of an interaction or single-term predictor (Table 1). Type $3 \mathrm{~F}$-statistics with Satterthwaite's approximation for degrees of freedom were used to assess the significance of the predictors in the best descriptive model, while pairwise comparisons were calculated based on differences of least square means (function difflsmeans, package "ImerTest," Kuznetsova and others 2017) (Table 2).

To further delineate the relative influence of microbial and termite decay, we first calculated the mean proportional mass loss of open blocks and closed blocks within each stratum (canopy, understory and ground) for each plot. Decomposition attributable to termites within each stratum was calculated by subtracting the mean proportional mass loss of closed blocks for each plot from the mean proportional mass loss of open blocks for each plot. If closed blocks had lost more mass than open blocks and the difference in mass loss be- tween open and closed blocks was not significant, then mean proportional mass loss was set to zero. This allowed for a logit transformation of mean proportional mass loss. We examined the relative contribution of microbes and termites by assessing differences in mean proportional mass loss using a logit-transformed linear model including decay agent (microbe/termite), strata and the interaction between these factors as fixed effects (for example, model $\leftarrow \operatorname{lm}$ (mean proportional mass loss $\sim$ decay agent * strata).

One tree was identified as a statistical outlier as patterns of decomposition in the understory, and canopy did not fit the general trend. Blocks on this tree showed far greater decomposition rates and evidence of mass termite decay: This may have been due to the presence of many epiphytes and arboreal soil on the tree which could preferentially lead to termite attack of the blocks. We discuss possible implications of this outlier, but data from this tree were omitted from the general analyses.

Temperature and humidity values were examined by first collating values across all trees (four trees) and days (20 days) and then calculating mean temperature and mean humidity for each height and time (every $30 \mathrm{~min}$ ) across a 24 -h period.

\section{RESUltS}

\section{Decomposition}

The decomposition of ground-placed CWD in open mesh bags was significantly greater than decomposition of suspended CWD (understory and canopy) (Figure 1A), and the interaction between mesh and stratum $\left(F_{2,119}=7.152, p<0.001\right)$ significantly influenced proportional mass loss. Pairwise comparisons (see Table 2) found that open blocks on the ground lost significantly more mass than open blocks in the canopy and understory and significantly more mass than closed blocks in all strata (ground, understory and canopy). However, there was little evidence for a systematic difference between closed and open blocks in either the canopy $(t=-0.192, d f=119, p=0.850)$ or understory $(t=0.016, d f=119, p=0.80)$. Over a period of 1 year, ground-placed CWD in open blocks lost a mean mass of $25.6 \%$ compared with $5.9 \%$ for suspended CWD in the canopy and $5.7 \%$ for suspended CWD in the understory.

When apportioning the relative influence of microbes and termites to decomposition, the interaction between decay agent (microbes or termites) and stratum significantly influenced mean 
Table 1. Comparative and Summary Statistics for Linear Mixed Models

\begin{tabular}{llrrr}
\hline Model & d.f. & LL & Dev & Pr $\left(>X^{2}\right)$ \\
\hline ML $\sim$ MT * S + (1|P) & 8 & 16.7018 & -33.404 & \\
ML $\sim$ MT + S + (1|P) & 6 & 9.6076 & -19.215 & $<0.001^{* * *}$ \\
ML $\sim$ S + (1|P) & 5 & 7.2031 & -14.406 & $<0.001^{* * *}$ \\
ML $\sim$ MT + (l|P) & 4 & 0.2430 & -0.486 & $<0.001^{* * *}$ \\
ML $\sim 1+(1 \mid \mathrm{P})$ & 3 & -1.5296 & 3.059 & $<0.001^{* * *}$
\end{tabular}

The response variable, proportional mass loss of CWD $(M L)$, in all linear mixed models was logit-transformed.

Explanatory variables included fixed effects of mesh type (MT) and strata (S), and a random effect of plot (P). Listed are the degrees of freedom (d.f.), log-likelihood (LL) and deviance (Dev). P values were calculated from Chi-squared likelihood ratio tests to assess the loss of explanatory power following the removal of an interaction or single-term predictor.

proportional mass loss $\left(F_{2,18}=7.142, p=0.005\right)$. The effect of microbes alone (that is, the closed block data) on the decay of blocks did not differ significantly among vertical strata. Mean proportional mass loss on the ground, attributable to microbes, did not differ significantly from microbial decomposition in the canopy (TukeyHSD, $p=0.990$ ) or understory (TukeyHSD, $p=1$ ) despite the trend for lower mass loss with height (Figure 1B). In contrast, block decomposition due to termites differed significantly among strata, and termite decomposition was significantly greater on the ground compared with the canopy (TukeyHSD, $p=0.001$ ) and understory (TukeyHSD, $p<0.001)$. The relative contribution of termites to decay of ground-placed CWD was greater than the relative contribution of microbial decay, although differences in mean proportional mass loss attrib- uted to termites and to microbes were not significant (TukeyHSD, $p=0.083$ ).

\section{Abiotic Conditions}

Temperature and humidity were vertically stratified with warmer, drier and more variable conditions evident in the canopy. The maximum temperature logged by the ibuttons ${ }^{\circledR}$ was $42.6^{\circ} \mathrm{C}$, and this was recorded in the canopy at a height of $40 \mathrm{~m}$. Temperature in the canopy, at $40 \mathrm{~m}$, varied on average by $12.5^{\circ} \mathrm{C}$ over the course of a day. In contrast, the maximum temperature recorded at $0 \mathrm{~m}$ was $36.1^{\circ} \mathrm{C}$ with a much lower mean range of $4.9^{\circ} \mathrm{C}$ over a 24 -h period (Figure 2 ). Maximum humidity of $100 \%$ was recorded at both $40 \mathrm{~m}$ and $0 \mathrm{~m}$. However, humidity showed much greater variation at $40 \mathrm{~m}$ compared with $0 \mathrm{~m}$, with a mean

Table 2. Effects of Mesh Type, Stratum and Plot on Proportional Mass Loss of CWD from the Best Descriptive Linear Mixed Model

\begin{tabular}{|c|c|c|c|c|c|}
\hline \multicolumn{6}{|l|}{ ANOVA } \\
\hline Fixed effects & Mean Sq & Num d.f. & Den $d . f$. & $F$ & $\operatorname{Pr}(>F)$ \\
\hline Mesh type ${ }^{*}$ strata & 0.33671 & 2 & 119 & 7.1519 & $0.001 * * *$ \\
\hline \multicolumn{6}{|c|}{ Pairwise comparisons using difflsmeans } \\
\hline & Estimate & SE & d.f. & $t$ & $\operatorname{Pr}(>|t|)$ \\
\hline $\mathrm{CM} \sim \mathrm{OM}$ & -0.10696 & 0.03915 & 119 & -2.7322 & $0.0073 * *$ \\
\hline $\mathrm{C} \sim \mathrm{G}$ & -0.22195 & 0.04925 & 119 & -4.5070 & $<0.001^{* * *}$ \\
\hline $\mathrm{G} \sim \mathrm{U}$ & 0.19775 & 0.04877 & 119 & 4.0548 & $<0.001^{* * *}$ \\
\hline $\mathrm{OM}: \mathrm{C} \sim \mathrm{OM}: \mathrm{G}$ & -0.37792 & 0.07129 & 119 & -5.3010 & $<0.001^{* * *}$ \\
\hline $\mathrm{OM}: \mathrm{G} \sim \mathrm{OM}: \mathrm{U}$ & 0.36813 & 0.07064 & 119 & 5.2117 & $<0.001 * * *$ \\
\hline $\mathrm{OM}: \mathrm{G} \sim \mathrm{CM}: \mathrm{U}$ & 0.35190 & 0.07064 & 119 & 4.9819 & $<0.001 * * *$ \\
\hline $\mathrm{CM}: \mathrm{C} \sim \mathrm{OM}: \mathrm{G}$ & -0.32453 & 0.07362 & 119 & -4.4080 & $<0.001^{* * *}$ \\
\hline $\mathrm{CM}: \mathrm{G} \sim \mathrm{OM}: \mathrm{G}$ & -0.39051 & 0.07129 & 119 & -5.4776 & $<0.001^{* * *}$ \\
\hline
\end{tabular}



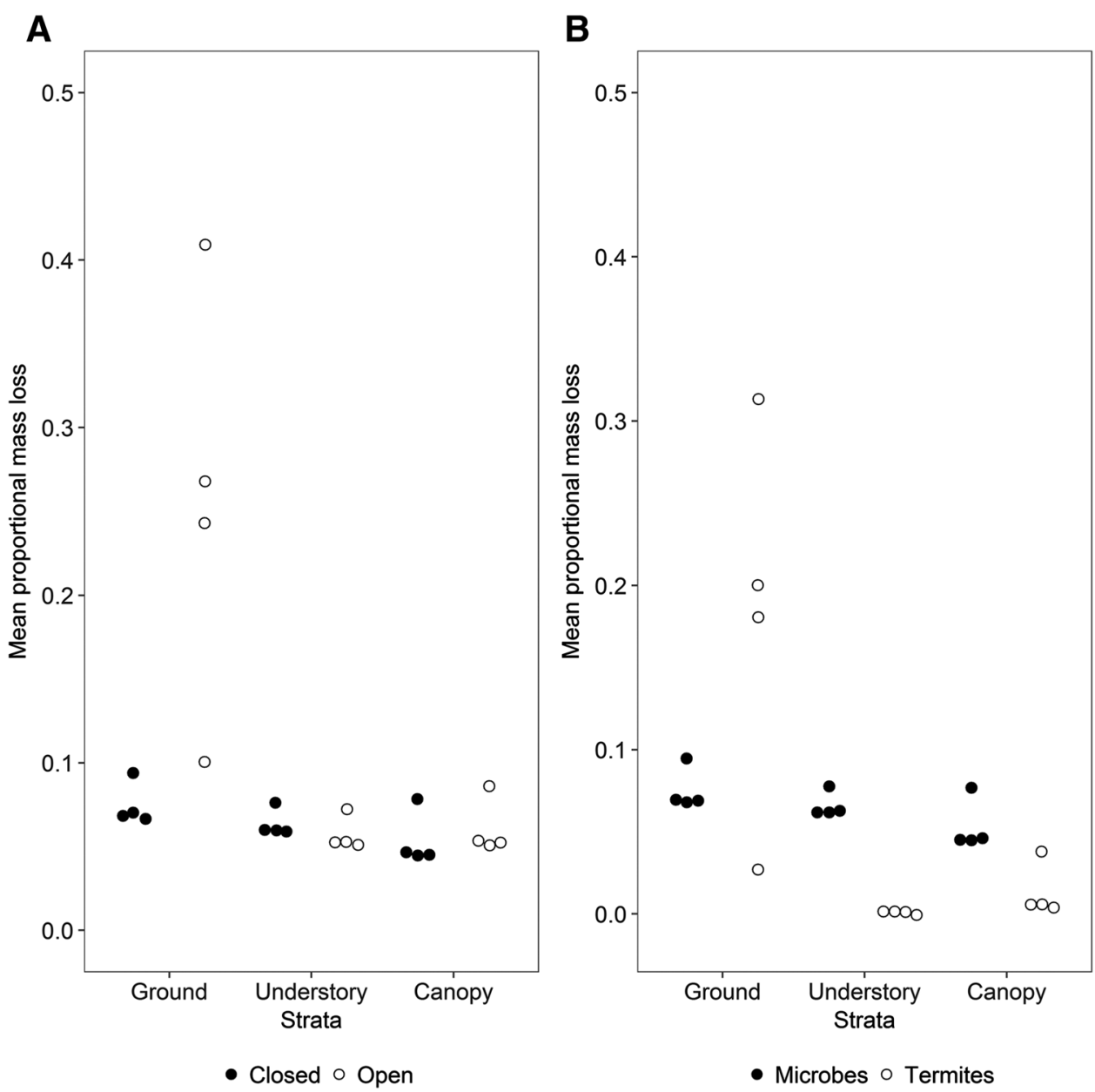

Figure 1. Dot plots showing (A) mean proportional mass loss of open and closed blocks among strata and (B) mean proportional mass loss of blocks where decay is attributed to microbes and to termites. Decay of closed blocks has been attributed to microbes (although microfauna and mesofauna may also contribute to decay), whereas decay attributed to termites has been calculated by the mean proportional mass loss of open blocks minus the mean proportional mass loss of closed blocks. For each stratum: mean proportional mass loss $=\Sigma$ proportional mass loss of blocks within each plot/ number of blocks within each plot, $n=4$ plots.

humidity range over $24 \mathrm{~h}$ of $52 \%$ compared with $17 \%$ at ground level (Figure 2). Lower humidity was observed in the canopy with a minimum humidity of $27 \%$ at $40 \mathrm{~m}$ compared with a minimum of $43 \%$ at $0 \mathrm{~m}$. The largest difference in mean temperature between the ground and the canopy was $6.6^{\circ} \mathrm{C}$, and the largest difference in mean humidity was $34 \%$; both occurred at 14:30.

\section{Discussion}

To our knowledge, this study and the study by Gora and others (In press a, b) represent the first to quantify decomposition or residence time of suspended CWD in tropical rainforest. Our findings revealed the slow rate of decay of suspended deadwood and the important role of microbial communities. We found large differences between decomposition of CWD at ground level and higher up in the canopy. The relative contribution by biotic decay agents (microbes and termites) to decomposition was affected by the vertical position of CWD, with termites making a large contribution to decomposition of ground-placed CWD (mean mass loss of $18 \%$ ) and a negligible contribution to suspended CWD (mean mass loss of $0 \%$ ). This seems to explain the large difference in overall decay rate in the different vertical strata.

Climatic differences between the ground and canopy have been cited as reasons for differences in decomposition rates of fallen and standing CWD due to the influence of temperature and water availability on saprotrophic microbial activity (Cheesman and others 2017; Song and others 
A Height $(\mathrm{m}) \cdot 0+5+10+15+20+25+30+35=40$

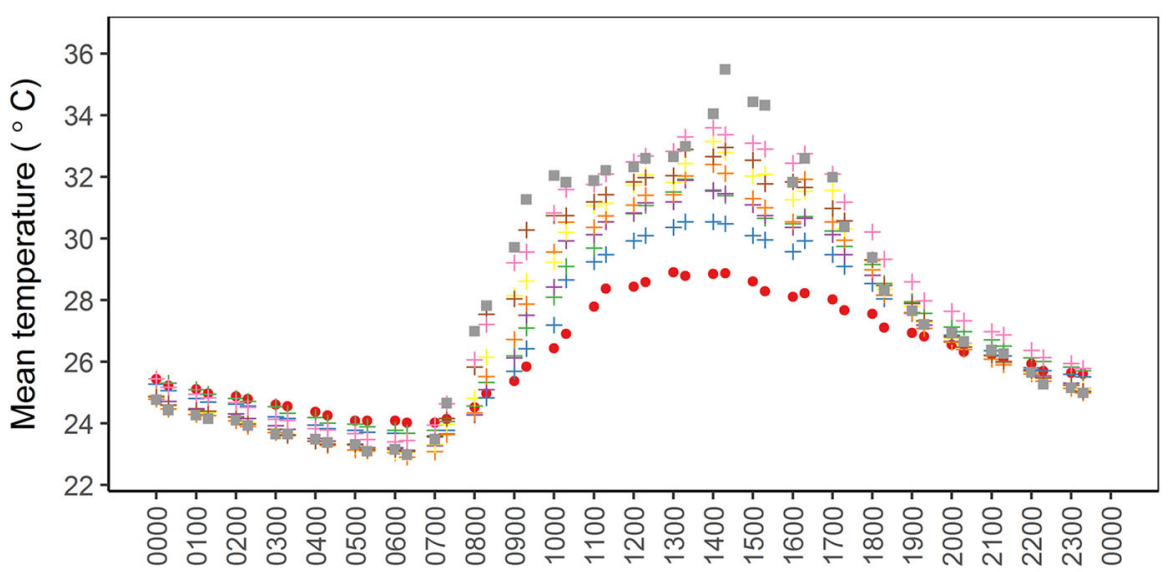

Time

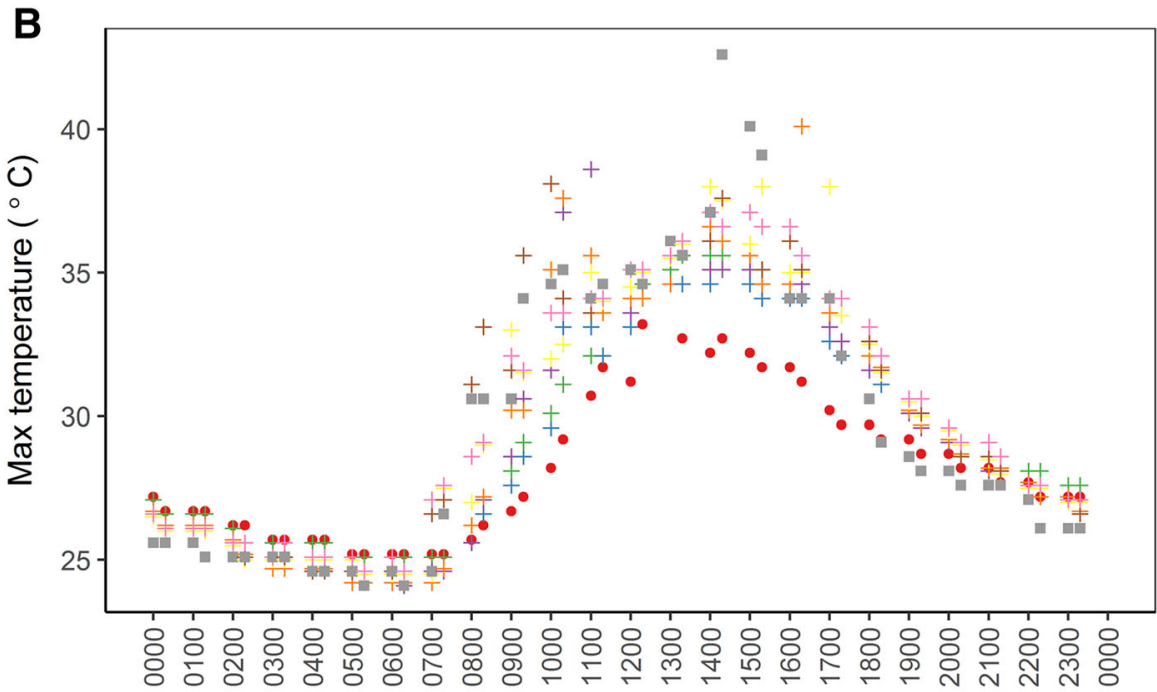

Time

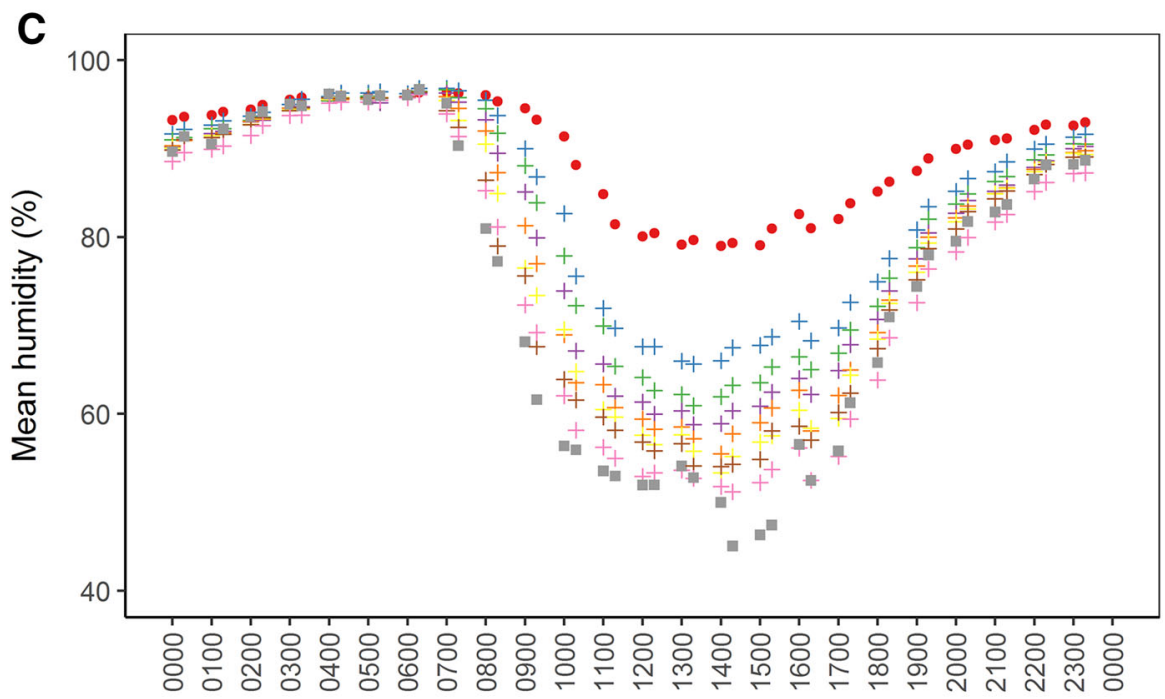

Time 
4Figure 2. (A) Mean temperature, (B) maximum temperature and $(\mathbf{C})$ mean humidity at $5-\mathrm{m}$ vertical intervals from the ground to the canopy across a 24-h period. Mean values were calculated by $\Sigma$ temperature or humidity at each height/number of observations. Observations were collated across all trees and 20 days.

2017). Saprotrophic microbial decomposition is dependent on optimal moisture availability and temperature, with extremes of either inhibiting decay (Harmon 1986). The large differences we found in temperature and humidity between the ground and the canopy (ground temperature was up to $7^{\circ} \mathrm{C}$ lower and $34 \%$ more humid) (Figure 2) are consistent with other studies (Madigosky 2004). This vertical climatic gradient, from the forest floor to the canopy, can be steeper than that found with changes in elevation and latitude (Scheffer and others 2013). However, despite the warmer, drier and more variable climatic conditions in the canopy (Figure 2), microbial decay of suspended CWD was comparable to the microbial part of decay of ground-placed CWD. In fact, microbial decay was low in all strata, with a mean mass loss of $7.5 \%$ on the forest floor, $6.4 \%$ in the understory and $5.4 \%$ in the canopy.

Although microbial decay apparently decreased with vertical height, there were no significant differences in mass loss among strata. This lack of evidence for differences may be an artifact of our sample size, and with a greater number of wood blocks, this trend of a decrease in microbial decomposition with height may become more apparent. Studies on the decomposers community in the canopy and the decomposition processes that occur here are rare (Stone and others 1996; Unterseher and Tal 2006). Although we did not collect data on the groups of microbes responsible for decay of fallen and suspended CWD, Gora and others (In press b) found that microbial community composition differed vertically with a shift from fungal to bacterial decomposers in the canopy.

Termites are known to affect rates of decay of fallen CWD in tropical rainforests (Wood and Sands 1978; Torres and Gonzalez 2005; Cheesman and others 2017) and are known to be present, albeit at low densities, in dead wood in forest canopies (Telles-Goncalves and others 2005; Roisin and others 2006). We therefore expected termites to influence decomposition of suspended CWD. However, our year-long study found that although the relative contribution by termites to the decay of ground-placed CWD was large, termites had little influence on the decomposition of suspended
CWD. While there are many arboreal-nesting termites in tropical rainforests, these termites often forage on the ground or do not feed on wood (for example, Hospitalitermes feeds on micro-epiphytes in the canopy) (Wood 1978; Wood and Sands 1978; Ellwood and others 2002; Bignell 2011). Furthermore, unlike fallen or standing CWD, dead wood suspended in the canopy is disconnected from the ground and is often not in direct contact with biotic decay agents; thus, it is even less likely to be discovered and attacked by termites resulting in slower rates of decomposition.

Termites are prone to desiccation, and their distribution is influenced by moisture and temperature levels; this is particularly true for subterranean termites due to their relatively unsclerotized body (Smith and Rust 1994; McManamy and others 2008; Cornelius and Osbrink 2010). Thus, differences in temperature and humidity between the ground and canopy (as shown in Figure 2) may contribute to the stratification in termite decay of CWD as lower humidities are likely to restrict feeding in the canopy to dry-wood specialist genera, such as the Kalotermitidae, which are more tolerant to desiccation (Collins 1969; Zukowski and Su 2017).

Low rates of termite decay in the canopy may also be attributed to the high densities of ants in the canopy, as wood blocks placed in the canopy were frequently occupied by ants (personal observations). In a temperate forest, Warren and Bradford (2012) found that ant colonization of fallen CWD corresponded with significantly less termite and fungal mediated decay. Predation by ants may deter termites from attacking CWD. In the canopy of tropical forests, there are particularly high densities of arboreal ants (Erwin 1989; Dial and others 2006) and low densities of termites (Telles-Goncalves and others 2005; Roisin and others 2006); this disparity between the two groups may further reduce the likelihood of termite attack on suspended CWD.

Although termite decomposition of suspended CWD was negligible in 35 out of the 36 trees sampled, one tree showed significant termite attack with a mean mass loss of $52.7 \%$ (range from 9.7 to $86.2 \%$ ) in open blocks (exposed to termites). The termite present in these blocks belonged to the genus Schedorhinotermes. Termites in this genus are characterized as wood-feeding, separate-piece nesters, meaning that they do not nest in their feeding substrate and instead actively forage for their feeding substrate (Eggleton and Tayasu 2001). This tree was omitted from analysis as a statistical outlier; nevertheless, the data are useful because they demonstrate that termites can have a significant 
impact on the decomposition of suspended CWD if the CWD is discovered while foraging. Although we have no data on aboveground termite density in this study, the low densities of canopy termites reported in other studies (Telles-Goncalves and others 2005; Roisin and others 2006) and the stochastic nature of termite foraging may explain the spatially variable effect of termite decay on suspended CWD. Given the artificial nature of our study, we recognize that further information regarding the distribution, abundance and activity of canopy dwelling termites is required to determine their importance in larger forest processes.

In our experiment, we used blocks of Pinus radiata as artificial representations of fallen and suspended CWD. A non-native, uniform substrate was used to enable comparisons of decomposition among different habitats and also to contribute to a wider global wood block study (Cheesman and others 2017). However, we recognize that there are a number of limitations from using pine. Because the pine blocks are a non-native conifer species, lack bark and are uniform in size and shape with a manipulated microenvironment due to the presence of mesh, it is likely that they decay differently from naturally occurring CWD. Although $P$. radiata is a substrate susceptible to termite attack (Standards Australia A5604- 2005), the absence of a phloem layer rich in sugars and a protective bark layer may exclude wood-decaying agents such as beetles that are often among the first to colonize dead wood, facilitate colonization by other decomposers and accelerate decomposition (Ulyshen and Wagner 2013; Ulyshen and others 2016; Dossa and others 2018). The differential rate of bark loss on naturally occurring CWD according to its physical location (Dossa and others 2018), be it fallen, standing or suspended, is likely to further drive variation in decay rates. Consequently, we have presented out results in light of comparing decay due to termites and it is likely that the decomposition rates reported here are conservative. It is also possible that the use of a non-native species, with low moisture content compared with naturally occurring CWD, may suppress some microbial mediated decay. Further work using a range of native species and naturally occurring CWD would be helpful to validate the use of artificial substrates like $P$. radiata in such experiments and to determine site- or species-specific decay rates of naturally occurring CWD.

We found that a period of 1 year in this study was not long enough for microbial decay to cause visible changes in the dead wood. Longer-term studies may reveal differences in the relative roles of biotic decay agents like termites and fungi, because as microbial decay alters the structural integrity and chemical composition of CWD it could become more susceptible to termite attack. Care should be taken in longer-term studies as the use of mesh bags may affect rates of decomposition by altering the microenvironment and increasing the water content of enclosed woody material (Stoklosa and others 2016), thus leading to greater differences in decomposition between experimental wood blocks and naturally occurring CWD. Conversely, the mesh could incur damage by UV degradation over a longer period of time, particularly when placed in the canopy.

Our study is significant because it demonstrates vertical partitioning of the major agents of decomposition. In the only tropical rainforest study on stocks of suspended CWD, Gora and others (In press a) observed that although suspended dead wood made a small contribution to total woody debris stocks around half of all woody debris is disconnected from the forest floor. Thus, the slow, microbial dominated decomposition that we observed in suspended CWD may be more applicable to larger proportions of CWD stocks than groundbased estimates of decomposition alone. We agree that categorization of CWD could be more functionally relevant to decomposition rates, that is, is the dead wood in direct contact with the forest floor. The lack of suspended CWD found by Gora and others (In press a) along with the highly variable spatial distribution of dead wood may in part explain the largely absent and stochastic role of canopy dwelling termites in decomposing suspended CWD as it represents an inconsistent food resource.

The importance of suspended dead wood to total stocks of woody debris is not clear. In temperate forests, stocks of suspended dead wood may be comparable to that of standing or fallen dead wood (Swift and others 1976; Christensen 1977). However, estimates for tropical forests are scarce. A review of dead wood in tropical forests by Palace and others (2012) reported that fallen CWD was measured 1.5 times more frequently than standing CWD and there was no mention of suspended CWD. The only study to have done so found that suspended dead wood made a small contribution to total stocks of woody debris (Gora and others a, In press). Yet a single study of one seasonal tropical rainforest system, compounded by the highly variable distribution of dead wood, is unlikely to be representative of all tropical forest systems. We recommend that when making estimates of carbon 
stocks in tropical rainforests, all forms of CWD, be it fallen, standing or suspended, should be surveyed.

The contribution made by suspended dead wood to whole forest carbon budgets is dependent not only on the volume of suspended CWD but also its residence time in the canopy. Only 35\% of papers reviewed by Palace and others (2012) actually measured decomposition, and the decay rate constant $(k)$ in undisturbed moist or wet tropical forests varied considerably from 0.03 to $0.46 \mathrm{y}^{-1}$. None had reported separate decay rates for standing and fallen CWD, let alone suspended CWD. The slow decomposition of suspended CWD we observed suggests a pool of carbon that is not being cycled quickly. To enable accurate estimations of nutrient return and carbon inputs of this largely unaccounted for pool of dead wood, we require a better understanding of decay rates. Our results contribute to existing research demonstrating large variation in decay rates of CWD depending on its physical location. We recommend that decay rates of all forms of CWD should be included in carbon models to estimate carbon flux in tropical rainforests accurately.

\section{ACKNOWLEDGEMENTS}

This publication is a contribution from the UK NERC-funded Biodiversity and Land-use Impacts on Tropical Ecosystem Function (BALI) consortium (http://bali.hmtf.info) (NERC Grant No. NE/ L000016/1) and was supported by the South-East Asian Rainforest Research Partnership (SEARRP) with permission from the Maliau Basin Management Committee. We are grateful for the University of Liverpool for funding the project. We thank all our wonderful, hardworking field assistants for making this work possible. Thank you to Professor Charles Vairappan of Universiti Malaysia Sabah for support throughout. Thank you to Dr Matthew Spencer of the University of Liverpool for reviewing this manuscript and providing valuable comments. We thank Glen Reynolds, Unding Jami and Laura Kruitbos for coordinating field work, and Sabine Both and Ully Kritzer for help in establishing the experimental plots.

\section{OPEN ACCESS}

This article is distributed under the terms of the Creative Commons Attribution 4.0 International License (http://creativecommons.org/licenses/by/4 $.0 /$ ), which permits unrestricted use, distribution, and reproduction in any medium, provided you give appropriate credit to the original author(s) and the source, provide a link to the Creative Commons license, and indicate if changes were made.

\section{REFERENCES}

Bates D, Maechler M, Bolker B, Walker S. 2015. Fitting linear mixed-effects models using lme4. J Stat Softw 67:1-48.

Bignell DE. 2011. Morphology, physiology, biochemistry and functional design of the termite gut: an evolutionary wonderland. In: Bignell DE, Roisin Y, Lo N, Eds. Biology of termites: a modern synthesis. New York: Springer. p 375-412.

Bignell DE, Eggleton P. 2000. Termites in ecosystems. In: Abe T, Higashi M, Bignell DE, Eds. Termites: evolution, sociality, symbioses, ecology. Dordrecht: Kluwer Academic Press. p 363-87.

Bradford MA, Warren RJII, Baldrian P, Crowther TW, Maynard DS, Oldfield EE, Wieder WR, Wood SA, King JR. 2014. Climate fails to predict wood decomposition at regional scales. Nat Clim Change 4:625-30.

Calderón-Cortés N, Escalera-Vásques LH, Oyama K. 2018. Occurrence of termites (Isoptera) on living and standing dead trees in a tropical dry forest in Mexico. PeerJ 6:e4731. http s://doi.org/10.7717/peerj.4731.

Chambers JQ, Schimel JP, Nobre AD. 2001. Respiration from coarse wood litter in central Amazon forests. Biogeochemistry 52:115-31.

Chambers JQ, Higuchi N, Schimel JP, Ferreira LV, Melack JM. 2000. Decomposition and carbon cycling of dead trees in tropical forests of the central Amazon. Oecologia 122:380-8.

Cheesman AW, Cernusak LA, Zanne AE. 2017. Relative roles of termites and saprotrophic microbes as drivers of wood decay: a wood block test. Aust Ecol. https://doi.org/10.1111/aec. 12561.

Christensen O. 1977. Estimation of standing crop and turnover of dead wood in a Danish Oak forest. Oikos 28:177-86.

Clark DB, Clark DA, Brown S, Oberbauer SF, Veldkamp E. 2002. Stocks and flows of coarse woody debris across a tropical rain forest nutrient and topography gradient. For Ecol Manag 164:237-48.

Collins M. 1969. Water relations in termites. In: Krishna K, Weesner FM, Eds. Biology of termites, Vol. 1. New York: Elsevier Academic Press. p 433-58.

Cornelius ML, Osbrink WLA. 2010. Effect of soil type and moisture availability on the foraging behaviour of the Formosan subterranean termite (Isoptera: Rhinotermitidae). J Econ Entomol 103:799-807.

Cornwell WK, Cornelissen JHC, Allison SD, Bauhuss J, Eggleton P, Preston CM, Scarff F, Weedon JT, Wirth C, Zanne AE. 2009. Plant traits and wood fates across the globe: Rotted, burned or consumed? Global Change Ecol 15:2431-49.

Cramer W, Bondeau A, Woodward I, Prentice C, Betts R, Brovkin V, Cox PM, Fisher V, Foley JA, Friend AD, Kucharik C, Lomas MR, Ramankutty N, Sitch S, Smith B, White A, Young-Molling C. 2001. Global response of terrestrial ecosystem structure and function to $\mathrm{CO}_{2}$ and climate change: results from six dynamic global vegetation models. Global Change Biol 7:357-73.

Delaney M, Brown S, Lugo AE, Torres-Lezama A, Quintero NB. 1998. The quantity and turnover of dead wood in permanent forest plots in six life zones of Venezuela. Biotropica 30:2-11. 
Dial RJ, Ellwood MDF, Turner EC, Foster WA. 2006. Arthropod abundance, canopy structure, and microclimate in a Bornean lowland tropical rain forest. Biotropica 38:643-52.

Dossa GGO, Schaefer D, Zhang JL, Tao JP, Cao KF, Corlett RT, Cunningham AB, Xu JC, Cornelissen JH, Harrison RD. 2018. The cover uncovered: bark control over wood decomposition. J Ecol. https://doi.org/10.1111/1365-2745.12976.

Dunn CJ, Bailey JD. 2012. Temporal dynamics and decay of coarse wood in early seral habitats of dry-mixed conifer forests in Oregon's eastern cascades. For Ecol Manag 276:71-81.

Eggleton P, Tayasu I. 2001. Feeding groups, life types and the global ecology of termites. Ecol Res 16:941-60.

Ellwood MDF, Jones DT, Foster WA. 2002. Canopy ferns in lowland dipterocarp forest support a prolific abundance of ants, termites, and other invertebrates. Biotropica 34:575-83.

Erwin TL. 1989. Canopy arthropod biodiversity: a chronology of sampling techniques and results. Revista Peruana de Entomologia 32:71-7.

Fonte SJ, Schowalter TD. 2004. Decomposition in Forest Canopies. In: Lowman MD, Rinker HB, Eds. Forest Canopies. Burlington: Elsevier Academic Press. p 413-22.

Gora EM, Kneale RC, Larjavaara M, Muller-Landau HC. Dead wood necromass in a moist tropical forest: stocks, fluxes, and spatiotemporal variability. Ecosystems (in press (a)).

Gora EM, Lucas JM, Yanoviak SP. Microbial composition and wood decomposition rates vary with microclimate from the ground to the canopy in a tropical forest. Ecosystems (in press (b)).

Griffiths HG, Ashton L, Walker A, Hasan F, Evans T, Eggleton P, Parr CL. 2017. Ants are the major agents of food resource removal from tropical rainforest floors. J Anim Ecol 00:1-8. https://doi.org/10.1111/1365-2656.12728.

Griffiths HG, Ashton LA, Evans TA, Parr CL, Eggleton P. Termites are responsible for more than half of decomposition in tropical rainforest. Curr Biol (in review).

Harmon ME, Sexton J. 1996. Guidelines for measurements of woody detritus in forest ecosystems. Seattle: University of Washington. p 73.

Harmon ME, Franklin JF, Swanson FJ, Sollins P, Gregory SV, Lattin JD, Anderson NH, Cline SP, Aumen NG, Sedell JR, Lienkaemper GW, Cromack K Jr, Cummins KW. 1986. Ecology of coarse woody debris in temperate ecosystems. Adv Ecol Res 15:133-302.

Harmon ME, Whigham DF, Sexton J, Olmsted I. 1995. Decomposition and mass of woody detritus in the dry tropical forests of the northeastern Yucatan peninsula, Mexico. Biotropica 27:305-16.

Iwashita DK, Litton CM, Giardina CP. 2013. Coarse woody debris carbon storage across a mean annual temperature gradient in tropical montane wet forest. For Ecol Manag 291:336-43.

Kuznetsova A, Brockhoff PB, Christensen RHB. 2017. lmerTest Package: tests in linear mixed effects models. J Stat Softw 82:1-26.

Liu G, Cornwell WK, Cao K, Hu Y, Van Logtestijn RSP, Yang S, Xie X, Zhang Y, Ye D, Pan X, Ye X, Huang Z, Dong M, Cornelissen JHC. 2015. Termites amplify the effects of wood traits on decomposition rates among multiple bamboo and dicot woody species. J Ecol 103:1214-23.

Maass JM, Martínez-Yrízar A, Patiño C, Sarukhán J. 2002. Distribution and annual net accumulation of above-ground dead phytomass and its influence on throughfall quality in a
Mexican tropical deciduous forest ecosystem. J Trop Ecol 18:821-34.

Mackensen J, Bauhus J, Webber E. 2003. Decomposition rates of coarse woody debris-a review with particular emphasis on Australian species. Aust J Bot 51:27-37.

Madigosky SR. 2004. Tropical microclimatic considerations. In: Lowman MD, Rinker HB, Eds. Forest canopies. Burlington: Elsevier Academic Press. p 24-48.

McManamy K, Koehler PG, Branscome DD, Pereira RM. 2008. Wood moisture content affects the survival of eastern subterranean termites (Isoptera: Rhinotermitidae), under saturated relative humidity conditions. Sociobiology 52:145-56.

Meentemeyer V. 1978. Macroclimate and lignin control of litter decomposition rates. Ecology 59:465-72.

Meentemeyer V. 1984. The geography of organic decomposition rates. Ann Assoc Am Geogr 74:551-60.

Moore TR, Trofymow JA, Taylor B, Prescott C, Camire C, Duschene L, Fyles J, Kozak L, Kranabetter M, Morrison I, Siltanen M, Smith S, Ttus B, Visser S, Wein R, Zoltai S. 1999. Litter decomposition rates in Canadian forests. Global Change Biol 5:75-82.

Onega TL, Eickmeier WG. 1991. Woody detritus inputs and decomposition kinetics in a southern temperate deciduous forest. Bull Torrey Bot Club 118:52-7.

Palace M, Keller M, Hurtt G, Frolking S. 2012. A review of above ground necromass in tropical forests. In: Sudarshana P, Nageswara-Rao M, Soneji JR, Eds. Tropical forests. Intech (online publisher). Published online at http://www.intechopen.c om/books/tropical-forests. pp 215-52.

Pan Y, Birdsey RA, Fang J, Houghton R, Kauppi PE, Kurz WA, Phillips OL, Shvidenko A, Lewis SL, Canadell JG, Ciais P, Jackson RB, Pacala SW, McGuire AD, Piao S, Rautiainen A, Sitch S, Hayes D. 2011. A large and persistent carbon sink in the world's forests. Science 333:988-93.

Parks CG, Shaw DC. 1996. Death and decay: a vital part of living canopies. Northwest Sci 70:46-53.

Roisin Y, Dejean A, Corbara B, Orivel J, Samaniego M, Leponce M. 2006. Vertical stratification of the termite assemblage in a neotropical rainforest. Oecologia 149:301-11.

Rice MD, Lockaby BG, Stanturf JA, Keeland BD. 1997. Woody debris decomposition in the Atchafalaya river basin of Louisiana following hurricane disturbance. Soil Sci Soc Am J 61:1264-74.

Rice AH, Pyle EH, Saleska SR, Hutyra L, Palace M, Keller M, de Camargo PB, Portilho K, Marques DF, Wofsy SC. 2004. Carbon balance and vegetation dynamics in an old-growth Amazonian forest. Ecol Appl 14(4):S55-71.

Scheffers BR, Phillips BL, Laurance WF, Sodhi NS, Diesmos A, Williams SE. 2013. Increasing arboreality with altitude: a novel biogeographic dimension. Proc R Soc B Biol Sci 280(1770):20131581.

Seibold S, Bässler C, Brandl R, Gossner MM, Thorn S, Ulyshen MD, Müller J. 2015. Experimental studies of dead-wood biodiversity-a review identifying global gaps in knowledge. Biol Conserv 191:139-49.

Smith JL, Rust MK. 1994. Temperature preferences of the western subterranean termite, Reticulitermes hesperus Banks. J Arid Environ 28:313-23.

Songwe NC, Okali DUU, Fasehun FE. 1995. Litter decomposition and nutrient release in a tropical rainforest, southern Bakundu forest reserve, Cameroon. J Trop Ecol 11:333-50. 
Song Z, Dunn C, Lü XT, Qiao L, Pang JP, Tang JW. 2017. Coarse woody decay rates vary by physical position in tropical seasonal rainforests of SW China. For Ecol Manag 385:206-13.

Standards Australia. 2005. Timber-natural durability ratings. AS 5604-2005. Standards Australia, Sydney, NSW, Australia.bib xml:id="bib50".

Stocklosa AM, Ulyshen MD, Fan Z, Varner M, Seibold S, Müller J. 2016. Effects of mesh bag enclosure and termites on fine woody debris decomposition in a subtropical forest. Basic Appl Ecol 17:463-70.

Stone JK, Sherwood MA, Carroll GC. 1996. Canopy microfungi: function and diversity. Northwest Sci 70:37-45.

Swift MJ, Healey IN, Hibberd JK, Sykes JM, Bampoe V, Nesbitt ME. 1976. The decomposition of branch-wood in the canopy and floor of a mixed deciduous woodland. Oecologia 26:13949.

Takamura K. 2001. Effect of termite exclusion on decay of heavy and light hardwood in a tropical rain forest of peninsular Malaysia. J Trop Ecol 17:541-8.

Telles Gonçalves T, DeSouza O, Reis R Jr, Pontes RS. 2005. Effect of tree size and growth form on the presence and activity of arboreal termites (Insecta: Isoptera) in the Atlantic rain forest. Sociobiology 46:1-12.

Torres JA, González G. 2005. Wood decomposition of Cyrilla racemiflora (Cyrillaceae) in Puerto Rican dry and wet forests: a 13-year case study. Biotropica 37:452-6.

Ulyshen MD. 2016. Wood decomposition as influenced by invertebrates. Biol Rev 91:70-85.

Ulyshen MD, Wagner TL. 2013. Quantifying arthropod contributions to wood decay. Methods Ecol Evolut 4:345-52.
Ulyshen MD, Müller J, Seibold S. 2016. Bark coverage and insects influence wood decomposition: direct and indirect effects. Appl Soil Ecol 105:25-30.

Unterseher M, Tal O. 2006. Influence of small scale conditions on the diversity of wood decay fungi in a temperate, mixed deciduous forest canopy. Mycological Res 110:169-78.

Warren RJII, Bradford MA. 2012. Ant colonization and coarse woody debris decomposition in temperate forests. Insects Sociaux 59:215-21.

Warton DI, Hui FKC. 2011. The arcsine is asinine: the analysis of proportions in ecology. Ecology 92:3-10.

Weedon JT, Cornwell WK, Cornelissen JHC, Zanne AE, Wirth C, Coomes DA. 2009. Global meta-analysis of wood decomposition rates: a role for trait variation among tree species. Ecol Lett 12:45-56.

Wood TG. 1978. Food and feeding habits of termites. In: Brian MV, Ed. Production ecology of ants and termites. Cambridge: Cambridge University Press. p 55-80.

Wood TG, Sands WA. 1978. The role of termites in ecosystems. In: Brian MV, Ed. Production ecology of ants and termites. Cambridge: Cambridge University Press. p 245-92.

Zukowski J, Su NY. 2017. Survival of termites (Isoptera) exposed to various levels of relative humidity $(\mathrm{RH})$ and water availability, and their RH preferences. Florida Entomologist 100:532-8.

Zuur A, Ieno EN, Walker N, Saveliev AA, Smith GM. 2009. Mixed effects models and extensions in ecology with R. New York: Springer. p 574. 